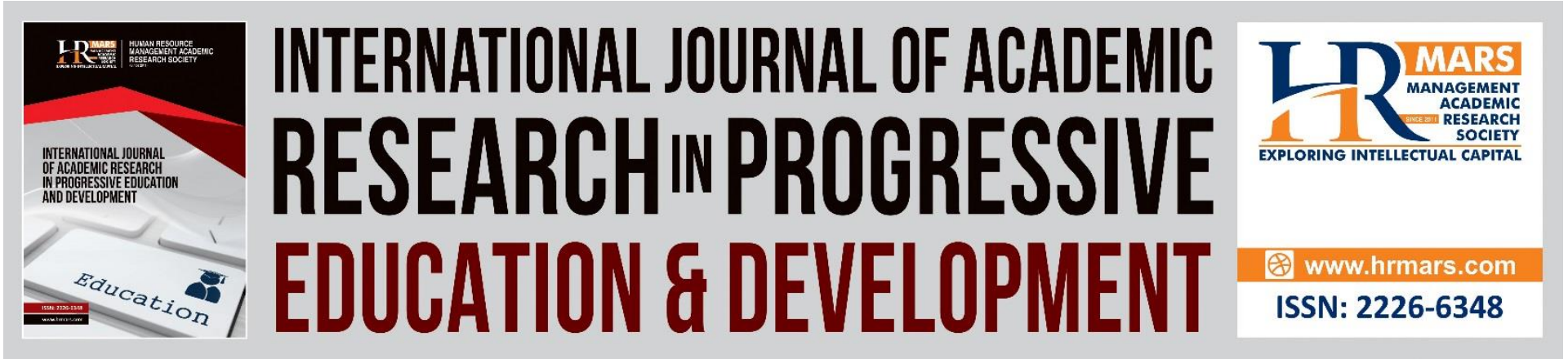

\title{
Teacher Commitment, Satisfaction and Stress During the Covid-19 Pandemic
}

Norazilawati Muhamad, Mohamad Syawal Amran and Shahlan Surat

To Link this Article: http://dx.doi.org/10.6007/IJARPED/v10-i3/10400

DOI:10.6007/IJARPED/v10-i3/10400

Received: 08 July 2021, Revised: 14 August 2021, Accepted: 30 August 2021

Published Online: 25 September 2021

In-Text Citation: (Muhamad et al., 2021)

To Cite this Article: Muhamad, N., Amran, M. S., \& Surat, S. (2021). Teacher Commitment, Satisfaction and Stress During the Covid-19 Pandemic. International Journal of Academic Research in Progressive Education and Development, 10(3), 852-865.

Copyright: (C) 2021 The Author(s)

Published by Human Resource Management Academic Research Society (www.hrmars.com)

This article is published under the Creative Commons Attribution (CC BY 4.0) license. Anyone may reproduce, distribute, translate and create derivative works of this article (for both commercial and non-commercial purposes), subject to full attribution to the original publication and authors. The full terms of this license may be seen

at: http://creativecommons.org/licences/by/4.0/legalcode

\section{Vol. 10(3) 2021, Pg. 852 - 865}

Full Terms \& Conditions of access and use can be found at http://hrmars.com/index.php/pages/detail/publication-ethics 


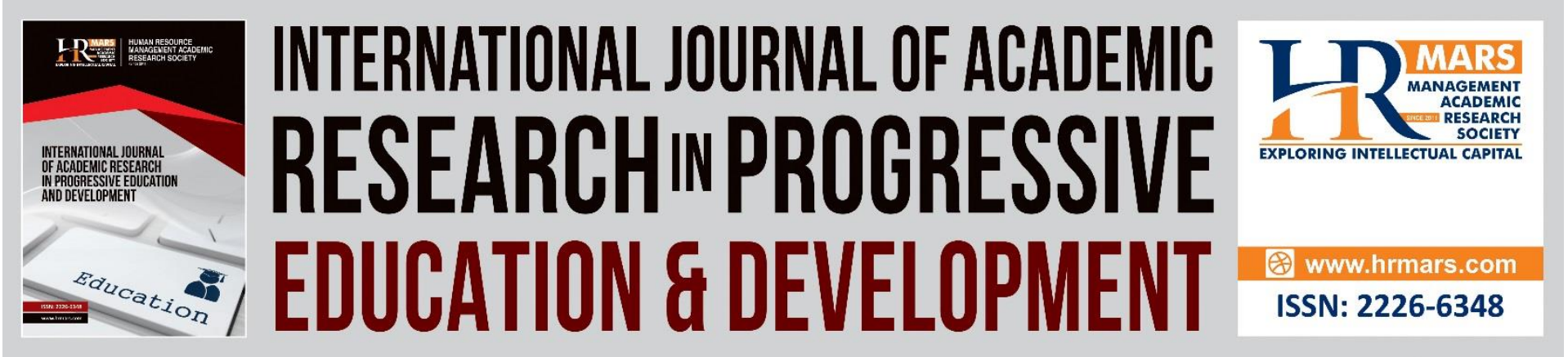

\title{
Teacher Commitment, Satisfaction and Stress During the Covid-19 Pandemic
}

\author{
Norazilawati Muhamad, Mohamad Syawal Amran and Shahlan \\ Surat \\ Falkulti Pendidikan, Universiti Kebangsaan Malaysia
}

\begin{abstract}
The Covid pandemic has triggered a phenomenon in Malaysia's education system in particular. This study aims to identify the level of commitment, satisfaction with teacher's stress during teaching and facilitation in Covid-19 pandemic situations among teachers. Data were obtained from 600 teachers through a questionnaire method using Statistical Package for Social Science (SPSS) software to obtain the analysis of this study. The analysis was done using a descriptive statistical method in the context of frequency, percentage and mean. The results of the study showed that the level of work commitment has a score (mean $=3.05, \mathrm{SP}$ $=0.533$ ) while job satisfaction has a score (mean $=3.19, \mathrm{SP}=0.473$ ) and work stress has a score (mean $=3.45, \mathrm{SP}=0.706$ ) among teachers while the implementation of virtual learning is at a moderate level overall. There are many factors that can be summarized for the level of commitment and satisfaction of virtual learning that caused stress among teachers during the pandemic. Among the factors are emotions, motivation, and workload at home and at school, pressure from the society on teachers and teacher's values. Increase of teacher's commitment and satisfaction can be enhanced with better infrastructure equipment to reduce teacher's stress during the pandemic.
\end{abstract}

Keywords: Teacher Commitment, Satisfactions, Stress, Pandemic, Covid-19, e-Learning.

\section{Introduction}

The COVID-19 pandemic indeed has a detrimental effect on health, education, economy, finance and others, resulting in several countries, including Malaysia, taking steps to implement the Movement Control Order (MCO). People are advised to stay at home, work from home (Work From Home) and restrict any movements outside as a preventive measure of this pandemic. The closure of higher education institutions and schools due to the COVID19 pandemic has affected the structure of a physical lesson to a fully online based learning. Various suitable digital applications or platforms such as Whatsapp, Google Classroom, Zoom, Webex, YouTube and so on are used to continue lesson activities even within the period of the Movement Control Order (MCO) as directed by the government. According to Affouneh et al (2020) in the digital age today, the use of information and communication technology (ICT) gives students the opportunity to apply the skills required in the 21st century. Accessibility, affordability, flexibility, learning pedagogy, lifelong learning, and policy are some 
of the arguments related to online pedagogy. It is said that the online learning mode is easily accessible and can even reach rural and inland areas, (Dhawan, 2020).

This online learning method requires commitment and cooperation from all parties, especially in terms of knowledge and skills related to information technology; provision of digital devices; quality internet access as well as the provision of appropriate assessment methods to measure students' achievement. The effects of online learning have completely caused emotional effects on teachers. As they are overwhelmed with the preparation of teaching materials; preparation of exercises; online teaching; Internet problems; students' attention span during their online learning and many other unforeseen circumstances. Deterioration of students' performance has always been associated with the quality of teachers' teaching and learning environments. This has also become one of the emotional effects on the teacher. In addition, parents and netizens are often putting emotional pressure on teachers over the closure of schools in Malaysia. Therefore, this study was conducted to look at the emotions and challenges of the teachers in online teaching due to school closures.

According to a study by Abdul Aziz (2020), stress can affect the society's mental health in Malaysia. This is due to the new norms that need to be adapted to the surrounding conditions, including online learning. Moderate stress can have a positive effect as it helps the body and mind to work properly. However, too much stress will have a negative impact on a person's health and achievement in whatever field the person is involved in (Abdul Rahman et al., 2011).

Online job satisfaction, according to the study of Safix et al (2021) stated that the level of job satisfaction is influenced by good and creative training management. Online training management can be done more efficiently if it provides improvements from all aspects so that the impact can be better. While satisfaction in terms of employment conditions depends on the suitability of human physical desires and the level of achievement of expected work goals. Junaidah et al (2013), the increase in job satisfaction of teachers can motivate them to continue their efforts to improve teaching skills, generate a better learning environment and improve students' achievement.

Teachers are the main catalyst entrusted in the process of application and transmission of knowledge to the new generation. This is because they are required to develop themselves with any form of change as well as renewal that takes place from time to time. The teaching profession is exposed to various pressures from within and without. Teachers who fail to control themselves due to stress will affect the teacher's relationship with students and the quality of teaching and learning. This in turn can affect the quality of education as well as the teaching profession which in turn will hinder efforts to create a society that is able to bring Malaysia to the level of excellence and glory of the quality of education.

Online learning or e-learning is a form of online teaching and learning at home delivered through the use of digital technology. E-learning is also a teaching method where the students are away from the teacher and the learning process is controlled by the students themselves. The teaching materials are used such as visual graphics, words, animations, video or audio. This learning process is easily implemented regardless of the distance and the number of students in it. Through e-learning, students can practice continuous learning while being able to convey knowledge more effectively. Online learning and teaching was a necessity in Malaysia when the Covid-19 pandemic occurred. 
Due to the COVID-19 pandemic, the teaching and learning methods that need to be channeled by teachers are different than usual. Through e-learning, it makes teachers feel more stressed due to school closures. Based on the researchers' observations during the online learning, there were many grievances and complaints from teachers in Malaysia about pressure from parents who were unhappy with the schools' closure and claimed that the teachers did nothing. Apart from that, the researchers have also found that many complaints from teachers in Malaysia are experiencing work stress in terms of time division in juggling work assignments and family responsibilities while working from home.

In conclusion, based on the discussion from previous studies, there are factors that contribute to the level of commitment and satisfaction of teachers during the Covid-19 pandemic. The study identified levels of teacher commitment, satisfaction and work stress during the Covid-19 pandemic.

\section{Literature Review}

The changes that happened in 2020 have caused a variety of pressures on teachers. This situation puts a significant impact on teachers. According to Gold \& Rothh (1993), the changes are one of the causes of stress for teachers. Therefore, teachers need to adapt and often be prepared for every impending change and always strive to add knowledge in various aspects. There are many past studies conducted to identify the levels and causes of stress among teachers.

Individuals who constantly deal with human beings as their clients such as teachers are more likely to face stress. There are three factors that cause stress among teachers, namely, student discipline problems that are difficult to control, the attitude of parents who often want the best results and the attitude of students who are smarter than teachers. All three of these factors are a source of stress among teachers (Thurayya, 2007).

According to a study by Cuiyan et al (2021), the Covid-19 Pandemic Impact on Physical and Mental Health in China and Spain showed that a total of 1528 respondents from Spain and China had symptoms similar to Covid-19 infection when they have a history of frequent use of medical services and lack of self-confidence. Spain reported that stress and depression were higher than Chinese respondents with an IES-R score $(P<.001)$. Meanwhile, Nor $(2020)$, stated that the cause of Malaysians experiencing psychological stress is due to several factors namely job loss, increased domestic violence, covid patients experience feelings of anxiety about the uncertainty of recovery and guilt because it may be the cause of disseminated disease, patients experience post-traumatic disorder (PTSD), obsessive disorder (OCD) patients, frontline workers struggling to deal with pandemics without leave and rest and those with the responsibility of managing the elderly, the sick and newborns.

According to a study conducted by the International of Research and Public Health, $53.8 \%$ of respondents reported moderate to severe psychological impacts. Of these, $16.5 \%$ had depressive symptoms, $28.8 \%$ had anxiety symptoms and $8.1 \%$ had stress. The results of the study found that women and students experienced the highest psychological impact. According to the $\mathrm{MOH}$ report (2020), as many as $46.8 \%$ suffer from emotional stress problems due to anxiety and anger. Each contributed a breakdown of $20 \%$ of feelings of anxiety about the epidemic, $6.9 \%$ of domestic violence problems, $6 \%$ of relationship problems, psychiatric problems namely depression and anxiety by $2.4 \%$ and $0.2 \%$ of child abuse. A UN study (2020), Covid-19 transmission is at risk of triggering a global mental health crisis. Reports show that there is an increase in the incidence of suicide in medical circles, anxiety and uncertainty 
among children, women at risk of domestic violence and confinement in the home and the elderly and patients facing chronic diseases and considered at risk of contracting the virus. The study also showed that the percentages of mental stress in Iran and the United States were $60 \%$ and $45 \%$, respectively.

Several psychological impacts have been identified including symptoms of depression, nervousness and stress. He added that the anxiety displayed by the community encourages various types of inappropriate behaviours such as panic buying, nervousness such as difficulty sleeping and feeling that his health is also disturbed. According to Changwon Son et al., (2020), the mental health effects of the pandemic in the United States stated that as many as $71 \%$ showed an increase in stress and anxiety as a result of the COVID-19 outbreak. Several stressors have been identified to contribute to increased levels of stress, anxiety, and depressed thinking among students. This includes fear and worries about their health and that of their loved ones. Whereas, 91\% reported negative effects from the pandemic, $89 \%$ difficulty concentrating, $86 \%$ disturbances in sleep patterns, $86 \%$ decreased social interaction due to physical distance, and $82 \%$ increased anxiety about academic performance. To cope with stress and anxiety, participants sought support from others and helped themselves by using negative or positive coping mechanisms.

The teachers commitment is the key to student success in the pandemic era. Virtual learning is the main approach chosen by teachers to conduct continuous learning. Various platforms are used by teachers to provide effective teaching impact, although there are time constraints to complete the syllabus without missing anything. The teachers in Malaysia give a very good commitment even though they have never faced new and drastic cultural changes as well as the addition of work assignments borne by teachers. Meanwhile, Rahayu's study (2020), states that 6 actions can be done by educators, namely solving complex environmental problems, practising effective communication, having flexibility, applying the latest technology, combining old and new concepts and being a facilitator of change.

Education through the virtual world is a new challenge for teachers, Professionalism in building a new generation of the country. Teachers equip themselves with mastery in digital technology as well as mastery of e-learning in imparting knowledge to students. All teachers improve their knowledge, competencies, abilities, skills, attitude change and readiness in accepting new norms through online learning (Daily News, 2020). It can be seen that the commitment of teachers is increasing both mentally and physically. In a study by Franciole et al (2021) the prevalence of anxiety, depression and stress among teachers during the Covid19 pandemic with mean scores of anxiety and depression were 4.35 and 4.38. Symptomatic rates of anxiety and depression (scores $>7$ in subscales of $14.15 \%$ and $17.35 \%$ ). The results of the study found that teachers who took fewer Chinese herbs, felt dissatisfied with standard operating procedures, felt higher infections, and lower health knowledge showed higher levels of anxiety and depression. This study also showed that women, married, living alone and wearing masks are more anxious. While young people, experiencing public health crises and not doing prevention have high levels of depression.

A study that was conducted by Vanderbilt University, USA (2015), found that almost $92 \%$ of students from various faculties agreed and were satisfied with online and effective learning compared to conventional teaching and learning at home. While $3 \%$ require physical pedagogy, 5\% are neutral (Awani, 2020). A study that has been done by Sakinah (2021), in the study of teaching physically better. The results showed that almost $60 \%$ of the students were 
absent during the e-learning session which was likely the absence or lack of gadgets, internet facility problems and others.

\section{Research Methodology}

The population of this study consists of teachers in Malaysia, namely national primary schools, national secondary schools, private primary schools/international primary schools and private secondary schools/international secondary schools in Peninsular Malaysia.

A simple sampling method was used to distribute 600 questionnaires to teachers throughout Malaysia. Researchers have chosen simple random sampling because the sample has been identified and the selection of the sample is based on the chance and probability of each respondent to be selected into the study sample. The respondents of this study answered the questionnaire with their own consent and willingness. Next, data were collected through the Teacher Stress Inventory instrument used by Boyle et al (1995) and it has been modified by Mokhtar (1998); Mazlan (2002) for use in the context of teachers in Malaysia. The Cronbach's Alpha reliability was 0.95 with the study significance level set at $\alpha=0.05$. The instrument was modified based on the context of the study.

Actual Data Reliability Table

\begin{tabular}{|l|l|l|}
\hline Variables & Alfa Cronbach & $\begin{array}{l}\text { Number of } \\
\text { Items }\end{array}$ \\
\hline Work of Comitment & 0.763 & 10 \\
\hline Job Satisfaction & 0.736 & 10 \\
\hline Work Pressure & 0.864 & 7 \\
\hline
\end{tabular}

The questionnaire was created using Google Form application software to enable respondents to complete the questionnaire online. This questionnaire is more focused on teacher stress during the online Teaching and Learning at Home process during the Covid-19 pandemic. Furthermore, the instructions and questions given in the questionnaire to all respondents surveyed were standard and similar. This can further increase the accuracy and truthfulness of the respondent's response to the question stimulus given because the respondent can respond to the standard question stimulus more effectively.

The questionnaire is divided into four parts, namely Part $A$ in the questionnaire is intended to obtain personal information related to age, gender, marital status, number of children, academic qualifications, teaching experience, educational institutions and citizenship status. Part B contains 14 items. This section aims to obtain information on the level of teacher commitment while working from home and implementing teaching and learning online from home. Section C contains 13 items. This section aims to obtain information on the level of teacher satisfaction in implementing teaching and learning online and working from home. Section $D$ contains 7 items. This section aims to obtain information on the level of teacher stress in implementing teaching and learning online and working from home.

All these questions are constructed in the form of closed-ended questionnaire items (close-ended questions) that are binary form and likert scale form. For answers in the form of 
DEVELOPMENT

Vol. 10, No. 3, 2021, E-ISSN: 2226-6348 @ 2021 HRMARS

this scale, the preparation of questions related to this study, in which the answers given by the respondents, should be filled in the form of a scale. This scale consists of Yes, Maybe and No for the Binary scale and four points for the Likert scale which is strongly agree, agree, disagree and not sure. In addition, methodology is the way in which researchers obtain information, materials, reference sources and data related to the study. In a study, the most important material is the study data. Without research data we never will get results. Therefore, the research data reviewed in the study conducted by the authors will produce a study related to the Commitment and Satisfaction of Teaching and Learning at Home Online Against Stress Among Teachers.

\section{Data Research}

\section{Respondent Background}

This study focuses on teachers in Peninsular Malaysia and a total of 600 people were involved in this study. A total of eight demographic characteristics was presented in tabular form based on the number and percentage of respondents. The demographic distribution of the respondents is shown in Table 4.1.

Table 4.1 Demographic Distribution of Respondents

\begin{tabular}{|l|l|l|}
\hline & Number & Percentage \\
\hline Gender & & \\
\hline Male & 69 & 11.5 \\
\hline Female & 531 & 88.5 \\
\hline Marital Status & & \\
\hline Single & 79 & 13.2 \\
\hline Married & 499 & 83.2 \\
\hline Widow & 22 & 3.7 \\
\hline Number of Children & & \\
\hline No & 123 & 20.5 \\
\hline $1-2$ & 137 & 22.8 \\
\hline $3-4$ & 242 & 40.3 \\
\hline More than 4 & 98 & 16.3 \\
\hline Academic Qualifications & & \\
\hline Master & 98 & 16.3 \\
\hline Bachelor & 472 & 78.7 \\
\hline Diploma & 30 & 5.0 \\
\hline Teaching Experience & & \\
\hline $1-10$ years & 128 & 21.3 \\
\hline $11-20$ years & 248 & 41.3 \\
\hline $21-30$ years & 183 & 30.5 \\
\hline More Than 30 years & 41 & 6.8 \\
\hline Institutions involved & & \\
\hline $\begin{array}{l}\text { Government Primary } \\
\text { School }\end{array}$ & 305 & 50.8 \\
\hline & & \\
\hline
\end{tabular}




\begin{tabular}{|l|l|l|}
\hline $\begin{array}{l}\text { Government Secondary } \\
\text { School }\end{array}$ & 257 & 42.8 \\
\hline $\begin{array}{l}\text { Private / International } \\
\text { Primary Schools }\end{array}$ & 25 & 4.2 \\
\hline $\begin{array}{l}\text { Private / International } \\
\text { Secondary Schools }\end{array}$ & 13 & 2.2 \\
\hline
\end{tabular}

\section{Teacher Work Commitment Level}

This study aims to answer the objectives and questions of the first study, which is to identify the level of work commitment among teachers during the Covid-19 dynamics. To give a clearer picture, the descriptive analysis is shown in Table 4.4 below.

Table 4.4 Frequency, Percentage, Mean and Standard Deviation of Teacher Work Commitment Level

\begin{tabular}{|c|c|c|c|c|c|c|c|c|}
\hline No & Statement & STS & TS & KS & $\mathbf{S}$ & SS & Mean & SD \\
\hline B1 & $\begin{array}{l}\text { I was able to adapt to online } \\
\text { teaching. }\end{array}$ & $\begin{array}{l}8 \\
(1.3)\end{array}$ & $\begin{array}{l}24 \\
(4.0)\end{array}$ & $\begin{array}{l}173 \\
(28.8 \\
)\end{array}$ & $\begin{array}{l}365 \\
(60.8 \\
)\end{array}$ & $\begin{array}{l}30 \\
(5.0)\end{array}$ & 3.64 & .701 \\
\hline B2 & $\begin{array}{l}\text { I operate online learning } \\
\text { applications effectively. For } \\
\text { example, Zoom, Google } \\
\text { Meet/Google Classroom, } \\
\text { Microsoft Team, Kahoot etc }\end{array}$ & $\begin{array}{l}15 \\
(2.5)\end{array}$ & $\begin{array}{l}52 \\
(8.7)\end{array}$ & $\begin{array}{l}190 \\
(31.7 \\
)\end{array}$ & $\begin{array}{l}294 \\
(49.0 \\
)\end{array}$ & $\begin{array}{l}49 \\
(8.2)\end{array}$ & 3.52 & .859 \\
\hline B3 & $\begin{array}{l}\text { The preparation of my } \\
\text { teaching equipment was } \\
\text { provided by the } \\
\text { administrator. For example, } \\
\text { laptops, cameras etc }\end{array}$ & $\begin{array}{l}337 \\
(56.2 \\
)\end{array}$ & $\begin{array}{l}151 \\
(25.2 \\
)\end{array}$ & $\begin{array}{l}73 \\
(12.2 \\
)\end{array}$ & $\begin{array}{l}32 \\
(5.3)\end{array}$ & $\begin{array}{l}7 \\
(1.2)\end{array}$ & 1.70 & .956 \\
\hline B4 & $\begin{array}{l}\text { The preparation of teaching } \\
\text { materials did not interfere } \\
\text { with my daily life and } \\
\text { essential tasks. }\end{array}$ & $\begin{array}{l}62 \\
(10.3 \\
)\end{array}$ & $\begin{array}{l}66 \\
(11.0 \\
)\end{array}$ & $\begin{array}{l}213 \\
(35.5 \\
)\end{array}$ & $\begin{array}{l}233 \\
(38.8 \\
)\end{array}$ & $\begin{array}{l}26 \\
(4.3)\end{array}$ & 3.16 & 1.030 \\
\hline B5 & $\begin{array}{l}\text { My economy was not } \\
\text { impressed in providing } \\
\text { teaching equipment } \\
\text { facilities. For example, } \\
\text { paying for Internet devices } \\
\text { and gadget equipment. }\end{array}$ & $\begin{array}{l}30 \\
(5.0)\end{array}$ & $\begin{array}{l}90 \\
(15.0 \\
)\end{array}$ & $\begin{array}{l}184 \\
(30.7 \\
)\end{array}$ & $\begin{array}{l}263 \\
(43.8 \\
)\end{array}$ & $\begin{array}{l}33 \\
(5.5)\end{array}$ & 3.30 & .960 \\
\hline B6 & $\begin{array}{l}\text { I don't feel physically tired } \\
\text { after teaching online. }\end{array}$ & $\begin{array}{l}72 \\
(12.0 \\
1\end{array}$ & $\begin{array}{l}99 \\
(16.5 \\
)\end{array}$ & $\begin{array}{l}211 \\
(35.2 \\
1\end{array}$ & $\begin{array}{l}196 \\
(32.7 \\
1\end{array}$ & $\begin{array}{l}22 \\
(3.7)\end{array}$ & 3.00 & 1.058 \\
\hline B7 & \begin{tabular}{lll}
\multicolumn{1}{c}{ don't feel mentally } \\
exhausted \\
online.
\end{tabular} & $\begin{array}{l}113 \\
(18.8\end{array}$ & $\begin{array}{l}154 \\
(25.7 \\
)\end{array}$ & $\begin{array}{l}216 \\
(36.0\end{array}$ & $\begin{array}{l}101 \\
(16.8 \\
)\end{array}$ & $\begin{array}{l}16 \\
(2.7)\end{array}$ & 2.59 & 1.057 \\
\hline
\end{tabular}




\begin{tabular}{|l|l|l|l|l|l|l|l|l|}
\hline B8 & $\begin{array}{l}\text { I can divide my time } \\
\text { between actual work } \\
\text { (teaching \& school work) } \\
\text { and housework while } \\
\text { working from home (WFH). }\end{array}$ & $\begin{array}{l}\text { (5.3) } \\
(11.5 \\
\text { ) }\end{array}$ & $\begin{array}{l}184 \\
(30.7 \\
)\end{array}$ & $\begin{array}{l}291 \\
(48.5 \\
)\end{array}$ & $\begin{array}{l}24 \\
(4.0)\end{array}$ & 3.34 & .926 \\
\hline B9 & $\begin{array}{l}\text { I managed to deliver online } \\
\text { teaching effectively. }\end{array}$ & $\begin{array}{l}59 \\
(9.8)\end{array}$ & $\begin{array}{l}118 \\
(19.7 \\
)\end{array}$ & $\begin{array}{l}271 \\
(45.2 \\
)\end{array}$ & $\begin{array}{l}145 \\
(24.2 \\
)\end{array}$ & $\begin{array}{l}7 \\
(1.2)\end{array}$ & 2.87 & .929 \\
\hline $\begin{array}{l}\text { B1 } \\
0\end{array}$ & $\begin{array}{l}\text { I complete administrative } \\
\text { work according to working } \\
\text { hours. }\end{array}$ & $\begin{array}{l}21 \\
(3.5)\end{array}$ & $\begin{array}{l}77 \\
(12.8 \\
)\end{array}$ & $\begin{array}{l}163 \\
(27.2\end{array}$ & $\begin{array}{l}305 \\
(50.8\end{array}$ & $\begin{array}{l}34 \\
(5.7)\end{array}$ & 3.42 & .909 \\
\hline & Total & & & & & & 3.05 & .533 \\
\hline
\end{tabular}

(Level: Very Low $=1.00-1.89$, Low $=1.90-2.69$, Medium $=2.70-3.49$, High $=3.50-4.29$, Very High $=4.30-5.00$ )

In this study, the level of work commitment was measured by 10 criteria. Table 4.4 shows two criteria had a high score, six criteria had a moderate score, one criterion had a low score and another criterion had a very low score. The results of this study showed that criteria B1 which is "I can adapt in teaching and learning at home online" recorded the highest mean (mean = 3.64, SP $=0.701$ ). Followed by criteria B2 which is "I operate online learning applications effectively. For example, Zoom, Google Meet/Google Classroom, Microsoft Team, Kahoot etc. "( mean = 3.52, SP = 0.859) and criteria B10 which is"I complete administrative work according to working hours " (mean $=3.42, \mathrm{SP}=0.909)$. While criteria B3 is "The preparation of my teaching equipment is provided by the administrator. For example, laptops, cameras etc. "recorded the lowest mean (mean $=1.70, \mathrm{SP}=0.956$ ). Overall, the score of the level of work commitment (mean $=3.05, \mathrm{SP}=0.533$ ) among teachers when the implementation of teaching and learning at home online is at a moderate level.

\section{Teacher Job Satisfaction Level}

This study aims to answer the objective and question of the second study, which is to identify the level of job satisfaction among teachers during the implementation of online pedagogy. To give a clearer picture, descriptive analysis is shown in Table 4.5 below. 
INTERNATIONAL JOURNAL OF ACADEMIC RESEARCH IN PROGRESSIVE EDUCATION AND DEVELOPMENT

Vol. 10, No. 3, 2021, E-ISSN: 2226-6348 @ 2021 HRMARS

Table 4.5 Frequency, Percentage, Mean and Standard Deviation of Teacher Job Satisfaction Level

\begin{tabular}{|c|c|c|c|c|c|c|c|c|}
\hline No & Statement & STS & TS & KS & $\mathbf{S}$ & SS & $\begin{array}{l}\text { Mea } \\
\mathrm{n}\end{array}$ & SD \\
\hline C1 & $\begin{array}{l}\text { The school provides class } \\
\text { schedules to suit teachers } \\
\text { who work from home. }\end{array}$ & $\begin{array}{l}10 \\
(1.7)\end{array}$ & $\begin{array}{l}32 \\
(5.3)\end{array}$ & $\begin{array}{l}66 \\
(11.0 \\
)\end{array}$ & $\begin{array}{l}422 \\
(70.3 \\
)\end{array}$ & $\begin{array}{l}70 \\
(11.7 \\
)\end{array}$ & 3.85 & .754 \\
\hline $\mathrm{C} 2$ & $\begin{array}{l}\text { The administrator gives } \\
\text { instructions/work during } \\
\text { working hours. }\end{array}$ & $\begin{array}{l}11 \\
(1.8)\end{array}$ & $\begin{array}{l}31 \\
(5.2)\end{array}$ & $\begin{array}{l}73 \\
(12.2 \\
1\end{array}$ & $\begin{array}{l}416 \\
(69.3 \\
1\end{array}$ & $\begin{array}{l}69 \\
(11.5 \\
)\end{array}$ & 3.83 & .763 \\
\hline C3 & $\begin{array}{l}\text { Administrators } \\
\text { understand the } \\
\text { difficulties of working } \\
\text { from home. }\end{array}$ & $\begin{array}{l}17 \\
(2.8)\end{array}$ & $\begin{array}{l}24 \\
(4.0)\end{array}$ & $\begin{array}{l}106 \\
(17.7 \\
)\end{array}$ & $\begin{array}{l}388 \\
(64.7 \\
)\end{array}$ & $\begin{array}{l}65 \\
(10.8 \\
)\end{array}$ & 3.77 & .804 \\
\hline C4 & $\begin{array}{l}\text { The presence of students } \\
\text { is very satisfying to the } \\
\text { teacher. }\end{array}$ & $\begin{array}{l}236 \\
(39.3 \\
1\end{array}$ & $\begin{array}{l}153 \\
(25.5 \\
)\end{array}$ & $\begin{array}{l}148 \\
(24.7 \\
)\end{array}$ & $\begin{array}{l}47 \\
(7.8)\end{array}$ & $\begin{array}{l}16 \\
(2.7)\end{array}$ & 2.09 & $\begin{array}{l}1.09 \\
0\end{array}$ \\
\hline C5 & $\begin{array}{l}\text { All students can respond } \\
\text { and collaborate during } \\
\text { online learning. }\end{array}$ & $\begin{array}{l}192 \\
(32.0 \\
1\end{array}$ & $\begin{array}{l}184 \\
(30.7 \\
)\end{array}$ & $\begin{array}{l}179 \\
(29.8 \\
)\end{array}$ & $\begin{array}{l}38 \\
(6.3)\end{array}$ & $\begin{array}{l}7 \\
(1.2)\end{array}$ & 2.14 & .979 \\
\hline C6 & $\begin{array}{l}\text { Pupils complete all the } \\
\text { exercises given by the } \\
\text { teacher each time the } \\
\text { exercises are given. }\end{array}$ & $\begin{array}{l}171 \\
(28.5 \\
)\end{array}$ & $\begin{array}{l}181 \\
(30.2\end{array}$ & $\begin{array}{l}193 \\
(32.2 \\
)\end{array}$ & $\begin{array}{l}49 \\
(8.2)\end{array}$ & $\begin{array}{l}6 \\
(1.0)\end{array}$ & 2.23 & .986 \\
\hline C7 & $\begin{array}{l}\text { All students submitted } \\
\text { the assigned exercises on } \\
\text { time. }\end{array}$ & $\begin{array}{l}188 \\
(31.3 \\
)\end{array}$ & $\begin{array}{l}196 \\
(32.7 \\
)\end{array}$ & $\begin{array}{l}183 \\
(30.5 \\
)\end{array}$ & $\begin{array}{l}28 \\
(4.7)\end{array}$ & $\begin{array}{l}5 \\
(0.8)\end{array}$ & 2.11 & .932 \\
\hline C8 & $\begin{array}{l}\text { Appreciations from } \\
\text { parents can increase the } \\
\text { teacher's level of } \\
\text { motivation. }\end{array}$ & $\begin{array}{l}8 \\
(1.3)\end{array}$ & $\begin{array}{l}13 \\
(2.2)\end{array}$ & $\begin{array}{l}43 \\
(7.2)\end{array}$ & $\begin{array}{l}375 \\
(62.5 \\
)\end{array}$ & $\begin{array}{l}161 \\
(26.8 \\
)\end{array}$ & 4.11 & .731 \\
\hline C9 & $\begin{array}{l}\text { Appreciation from } \\
\text { administrators can } \\
\text { increase the level of } \\
\text { teacher motivation. }\end{array}$ & $\begin{array}{l}5 \\
(0.8)\end{array}$ & $\begin{array}{l}4 \\
(0.7)\end{array}$ & $\begin{array}{l}20 \\
(3.3)\end{array}$ & $\begin{array}{l}373 \\
(62.2 \\
)\end{array}$ & $\begin{array}{l}198 \\
(33.0 \\
)\end{array}$ & 4.26 & .632 \\
\hline $\begin{array}{l}\text { C1 } \\
0\end{array}$ & $\begin{array}{l}\text { I was able to provide the } \\
\text { complete equipment for } \\
\text { online teaching. For } \\
\text { example, computers, } \\
\text { internet devices, } \\
\text { scanners, cameras etc. }\end{array}$ & $\begin{array}{l}21 \\
(3.5)\end{array}$ & $\begin{array}{l}56 \\
(9.3)\end{array}$ & $\begin{array}{l}167 \\
(27.8 \\
)\end{array}$ & $\begin{array}{l}298 \\
(49.7 \\
)\end{array}$ & $\begin{array}{l}58 \\
(9.7)\end{array}$ & 3.53 & .917 \\
\hline & Total & & & & & & 3.19 & .473 \\
\hline
\end{tabular}

(Level: Very Low $=1.00-1.89$, Low $=1.90-2.69$, Medium $=2.70-3.49$, High $=3.50-4.29$, Very High $=4.30-5.00$ ) 
In this study, the level of job satisfaction was measured by 10 criteria. Table 4.5 shows six criteria had high scores, while another four criteria had low scores. The results of this study showed that criteria C9 which is "Words of appreciation from the administrator can increase the level of teacher motivation" recorded the highest mean (mean $=4.26, \mathrm{SP}=0.632$ ). Followed by criteria C8 which is "Words of appreciation from parents can increase the level of teacher motivation" (mean $=4.11, \mathrm{SP}=0.731$ ) and criteria $\mathrm{C} 1$ which is "The school provides class schedules suitable for teachers who work from home" (mean $=3.85, \mathrm{SP}=0.754$ ). While criteria C4, "Attendance of students is very satisfactory to the teacher" recorded the lowest mean (mean $=2.09, \mathrm{SP}=1.0901)$. Overall, the job satisfaction level score (mean $=3.19, \mathrm{SP}=$ 0.473) among teacher teachers when the implementation of PdPr online was at a moderate level.

\section{Teacher Work Stress Level}

This study aims to answer the objective and question of the third study, which is to identify the level of work stress among teachers during the implementation of online lessons. To give a clearer picture, the descriptive analysis is shown in Table 4.6 below.

Table 4.6 Frequency, Percentage, Mean and Standard Deviation of Teacher Work Stress Levels

\begin{tabular}{|c|c|c|c|c|c|c|c|c|}
\hline No & Statement & STS & TS & KS & $S$ & SS & Mean & SD \\
\hline D1 & $\begin{array}{l}\text { Infrastructure constraints } \\
\text { such as internet lines, } \\
\text { internet devices, laptops, } \\
\text { printers etc are the main } \\
\text { causes of stress on } \\
\text { teachers during online } \\
\text { learning. }\end{array}$ & $\begin{array}{l}12 \\
(2.0 \\
)\end{array}$ & $\begin{array}{l}31 \\
(5.2)\end{array}$ & $\begin{array}{l}91 \\
(15.2 \\
)\end{array}$ & $\begin{array}{l}317 \\
(52.8 \\
)\end{array}$ & $\begin{array}{l}149 \\
(24.8 \\
)\end{array}$ & 3.93 & .885 \\
\hline D2 & $\begin{array}{l}\text { I experienced prolonged } \\
\text { emotional stress as a result } \\
\text { of problems working from } \\
\text { home. }\end{array}$ & $\begin{array}{l}43 \\
(7.2 \\
)\end{array}$ & $\begin{array}{l}134 \\
(22.3 \\
)\end{array}$ & $\begin{array}{l}238 \\
(39.7 \\
)\end{array}$ & $\begin{array}{l}152 \\
(25.3 \\
)\end{array}$ & $\begin{array}{l}33 \\
(5.5)\end{array}$ & 3.00 & .992 \\
\hline D3 & $\begin{array}{l}\text { I find the workload of Work } \\
\text { From Home excessive } \\
\text { compared to working at } \\
\text { school. }\end{array}$ & $\begin{array}{l}19 \\
(3.2 \\
)\end{array}$ & $\begin{array}{l}47 \\
(7.8)\end{array}$ & $\begin{array}{l}153 \\
(25.5 \\
)\end{array}$ & $\begin{array}{l}245 \\
(40.8 \\
)\end{array}$ & $\begin{array}{l}136 \\
(22.7 \\
)\end{array}$ & 3.72 & 1.002 \\
\hline D4 & $\begin{array}{l}\text { Parents/guardians put } \\
\text { pressure on my online } \\
\text { pedagogy during the } \\
\text { lesson. }\end{array}$ & $\begin{array}{l}41 \\
(6.8 \\
)\end{array}$ & $\begin{array}{l}169 \\
(28.2 \\
)\end{array}$ & $\begin{array}{l}285 \\
(47.5 \\
)\end{array}$ & $\begin{array}{l}81 \\
(13.5\end{array}$ & $\begin{array}{l}24 \\
(4.0)\end{array}$ & 2.80 & .900 \\
\hline D5 & $\begin{array}{l}\text { I find that online learning is } \\
\text { a workload for teachers. }\end{array}$ & $\begin{array}{l}20 \\
(3.3 \\
1\end{array}$ & $\begin{array}{l}77 \\
(12.8 \\
)\end{array}$ & $\begin{array}{l}209 \\
(34.8 \\
)\end{array}$ & $\begin{array}{l}230 \\
(38.3 \\
1\end{array}$ & $\begin{array}{l}64 \\
(10.7 \\
)\end{array}$ & 3.40 & .955 \\
\hline D6 & $\begin{array}{l}\text { I find that online learning } \\
\text { increases stress on } \\
\text { teachers. }\end{array}$ & $\begin{array}{l}16 \\
(2.7 \\
)\end{array}$ & $\begin{array}{l}58 \\
(9.7)\end{array}$ & $\begin{array}{l}144 \\
(24.0\end{array}$ & $\begin{array}{l}303 \\
(50.5\end{array}$ & $\begin{array}{l}79 \\
(13.2\end{array}$ & 3.62 & .924 \\
\hline
\end{tabular}




\begin{tabular}{|l|l|l|l|l|l|l|l|l|}
\hline D7 & $\begin{array}{l}\text { Overall, I feel pressured to } \\
\text { teach online as opposed to } \\
\text { a physical class. }\end{array}$ & $\begin{array}{l}22 \\
(3.7\end{array}$ & $\begin{array}{l}48 \\
(8.0)\end{array}$ & $\begin{array}{l}134 \\
(22.3\end{array}$ & $\begin{array}{l}272 \\
(45.3\end{array}$ & $\begin{array}{l}124 \\
(20.7\end{array}$ & 3.71 & 1.000 \\
\hline & Total & & & & & & $\mathbf{3 . 4 5}$ & $\mathbf{. 7 0 6}$ \\
\hline
\end{tabular}

(Level: Very Low $=1.00-1.89$, Low $=1.90-2.69$, Medium $=2.70-3.49$, High $=3.50-4.29$, Very High $=4.30-5.00$ )

In this study, work stress levels were measured by 7 criteria. Table 4.6 shows four criteria had high scores, while the other three criteria had moderate scores. The results of this study showed that criteria D1 which is "Infrastructure constraints such as Internet lines, internet devices, laptops, printers, etc. are the main causes of stress on teachers during online learning" recorded the highest mean (mean $=3.93 \mathrm{SP}=0.885$ ). Followed by criteria D3 which is "I find the workload 'Work From Home' is excessive compared to working at school" (mean $=3.72, \mathrm{SP}=1.002$ ) and criteria D7 which is "Overall, I feel pressured to teach online rather than face to face in class" (mean $=3.71, S P=1,000)$. While criteria D4, "Parents/guardians put pressure on my PdPr during teaching" recorded the lowest mean (mean $=2.80, \mathrm{SP}=0.900$ ). Overall, the work stress level score (mean $=3.45, \mathrm{SP}=0.706$ ) among teacher teachers when the implementation of PdPr online was at a moderate level.

\section{Discussion}

In this study, the researcher has used the research tool of the questionnaire method and used the statistical package for social science version 23 (SPSS) software to obtain the analysis of this study. To obtain raw data related to the study, researchers have used a question naire instrument. This study was conducted using a questionnaire method based on the Teacher Stress Inventory instrument used by Boyle et al (1995) and it was modified by Mokhtar (1998); Mazlan (2002), Job Description Index by Smith et al (1969) for the satisfaction question and the Organizational Commitment Questionnaire by Mowday et al (1979) for the question of commitment to be used in the context of teachers in Malaysia.

The results showed that the level of work commitment was measured among teachers during the implementation of online learning which was measured by 10 items. The findings of the study showed that two items had a high score, six items had a moderate score, one item had a low score and another item had a very low score. Overall it shows that the work commitment among teacher educators during the implementation of online learning is able to adapt and adapt to online teaching and learning at home or e-learning during the dynamics.

The results of the study showed the level of job satisfaction among teachers during the implementation of online teaching and learning at home measured by 10 items. The findings of the study showed that six items had high scores, while another four items had low scores. Overall, showing the level of job satisfaction scores among teachers as educators during the implementation of online teaching and learning online at home is not encouraging, especially the attendance of students during e-learning.

The results showed the level of work stress among teachers during the implementation of online teaching and learning at home. The findings of the study showed that four items had high scores, while the other three items had moderate scores. Overall, showing the work stress level scores among teachers as educators during the implementation of online teaching and learning at home, was the infrastructure factor, which was the main 
cause of stress on teachers during e-learning. The overall findings of the study show that the level of commitment, satisfaction and work stress among teachers during the implementation of online teaching and learning at home is at a moderate level overall.

\section{Conclusion}

Job commitment and job satisfaction are one of the factors of effectiveness in reducing stress for teachers when online teaching and learning online at home takes place regardless of whether online learning or face-to-face learning. In conclusion, the researchers suggested that administrators should provide IT training and conduct workshops to improve teachers' IT skills, preparation of notes and various interesting exercises in order to attract students attention in the classroom virtually and get cooperation from parents by providing support and motivation to their children in the face of virtual learning. Researchers hope that this study can help teachers, parents and schools to see the level of work commitment and job satisfaction of teachers, to the pressure faced by teachers in Malaysia during online lessons. Knowing the level of work commitment and satisfaction of online lessons against item-based stress allows administrators, parents and the community to behave appropriately towards the school and teacher's personal change towards the improvement of online lessons. The moderate stress among individuals is good for stimulating the mind to achieve excellent performance compared to no stress at all. This is because not all stress is harmful. A little pressure given to a person can be a source of motivation or a driving factor for a better direction. When a person is in a state of little stress it will cause a person to ensure that oneself is in a state of readiness, competitiveness and viability.

\section{Reference}

Abdul, A. R., Mohd, S., \& Abdul, R. (2020). Wabak COVID-19: Pengurusan Aspek Kesihatan Mental Semasa Norma Baharu. International Journal of Social Science Research, Vol.2. (4), 156-174. http://myjms.mohe.gov.my/index.php/ijssr

Affouneh, S., Salha, S. N., Khlaif, Z. (2020). Designing quality e-learning environments for emergency remote teaching in coronavirus crisis. Interdisciplinary Journal of Virtual Learning in Medical Sciences, 11(2), 1-3. [Google Scholar]

American Psychological Association. (2020). Stress in America: A National Mental Health Crisis. Retrieved on 12 October. https://www.apa.org/news/press/releases/ stress/2020/sia-mental-health-crisis.pdf

Ahmad, A. (2020). Bebas New Minda Bebas Columnists. Cabaran Menandakan Tugasan pelajar secara dalam talian. Retrieved on 7 May https://bebasnews.my/?p=34305

Boyle, G. J., Borg, M. G., Falzon, J. M., \& Baglioni, A. J. (1995). A structural model of the dimensions of teacher stress. British Journal of Educational Psychology, 65(1), 4967. https://doi.org/10.1111/j.2044-8279.1995.tb01130.x

Wang, C., López-Núñez, M. I., Pan, R., Wan, X., Tan, Y., Xu, L., Choo, F., Ho, R., Ho, C., \& Aparicio García, M. E. (2021). The Impact of the COVID-19 Pandemic on Physical and Mental Health in China and Spain: Cross-sectional Study. JMIR formative research, 5(5), e27818. https://doi.org/10.2196/27818

Gold, Y., \& Roth, R. A. (1993). Teachers Managing Stress and Preventing Burn-Out: The Professional Health Solution. London: Falmer Press.

Junaidah, M., \& Rosila, N. Y. (2013). A Study on Job Satisfaction Among Special Education Teachers. Asia Pacific Journal of Educators and Education, Vol. 28, 103-115. 
Safix, M., Aznie, R. C. R., Muhammad, D. J., Rogis B., \& Mohd, S. I. (2021). Pengaruh Latihan Bercirikan Ketenteraan Keatas Pembangunan Prestasi Pekerja: Organisasi Sektor Awam Di Malaysia. Malaysian Journal of Social Sciences and Humanities, Vol. 6, 53 - 64. https://doi.org/10.47405/mjssh.v6i2.631

Nor, H. (2020). Emosi, usaha membendung dan konsep tawakal. Tekanan Psikologikal Sewaktu COVID-19. Universiti Tun Hussein Onn Malaysia (UTHM).

Rahayu, A. B. (2020). Peranan dan Cabaran Pemimpin Pendidikan Dalam Memastikan Matlamat Dan Agenda Pendidikan Dilestari Dalam Tempoh Perintah Kawalan Pergerakan (PKP) Covid-19. Retrieved on 12 October 2020.

http://iab.moe.edu.my/index.php/ms/sumber/menu-berita-pemberitahuan/743covid-19

Dhawan, S. (2020). Online Learning: A Panacea in the Time of COVID-19 Crisis. Journal of Educational Technology Systems, 49(1), 5-

22. https://doi.org/10.1177/0047239520934018

Thurayya, O., Syed, M., Syed, M. S. (2007) Hubungan Burnout Dengan Kepuasan Kerja di Kalangan Staf Jabatan Agama Johor. Unpublished Master's thesis, Universiti Teknologi Malaysia. http://merr.utm.my/id/eprint/10715 